\title{
Using Crowdsourcing Based Health-map System in Bangladesh: Prospects, Challenges, and Development of an Effective Model
}

\author{
Moinul Islam Sayed ${ }^{1}$, Md. Mamun-ur-Rashid ${ }^{2}$ and Rejwana Islam ${ }^{3}$ \\ ${ }^{1}$ Department of Computer Science and Information Technology, Patuakhali Science and Technology \\ University, Patuakhali, Bangladesh \\ ${ }^{2}$ Department of Agricultural Extension and Rural Development, Patuakhali Science and Technology \\ University, Patuakhali, Bangladesh \\ ${ }^{3}$ Department of Computer Science and Engineering, Global University Bangladesh, \\ Barishal, Bangladesh
}

Correspondence should be addressed to: Md. Mamun-ur-Rashid; murashidpstu@gmail.com

Received date: 25 May 2018; Accepted date: 25 September 2018; published date: 13 March 2019

Academic Editor: Noor'ain Mohamad Yunus

Copyright (C) 2019. Moinul Islam Sayed, Md. Mamun-ur-Rashid and Rejwana Islam. Distributed under Creative Commons CC-BY 4.0

\begin{abstract}
Despite a countrywide mobile network and a massive number of subscribers, Bangladesh till now failed to usurp the full potential of e-health service. With the aim of analyzing the prospects and challenges of using crowdsouring based health-map system in Bangladesh, this study adopts a mixed method approach and collect data using structured questionnaire, key informant interview, in-depth interview, informal interview, focus group discussion, case study, etc. The results of this research represent that, except for a small proportion $(11 \%)$, the majority (89\%) of the respondents don't go to doctors for minor health related problems. The major causes of not going to the doctor encompass high crowdedness in the hospital, high visiting charge of the doctors, etc. Television, mobile phone, and internet are three main sources of receiving health related information. The lion's share $(76 \%)$ of the respondents have interest in e-health service, but cynically a minor(22\%) section of the respondents ever used e-health service. Present mobile phone based e-health services have several problems such as no preservation of patient's record, no scope of continuous contact with the same doctor, and hectic procedure in reaching a doctor. This study proposes a crowdsourcing based e-health service model, which will help to create a massive data set and assist in both treatment of the patient and predict future outbreaks of health crisis.
\end{abstract}

Keywords: Prospects; Challenges; Crowdsourcing; Health-map; Bangladesh.

Cite this Article as: Moinul Islam Sayed, Md. Mamun-ur-Rashid and Rejwana Islam (2019)," Using Crowdsourcing Based Health-map System in Bangladesh: Prospects, Challenges, and Development of an Effective Model", Journal of e-health Management, Vol. 2019 (2019), Article ID 673705, DOI: $10.5171 / 2019.673705$ 


\section{Introduction}

Bangladesh is a developing country, where over one third of the population is living in poverty and another one third live just above poverty level (The World Bank, 2010). Despite this backdrop, Bangladesh has achieved substantial progress in some sectors of health such as reduction of infant mortality, under 5 mortality, and maternal mortality, etc. (World Health Organization \&Ministry of Health and Family Welfare, 2015). Projection of mortality and health related indicators from the period 1990 to 2014 displayed in Table 1 also show a sizeable progress in the health sector of the country. However, despite a substantial progress in reducing child and infant mortality, Bangladesh still has poor prenatal and postpartum care, nutritional deficiencies, high incidence of non-skilled birth attendant utilization and the second highest maternal mortality and morbidity rates next to sub Saharan Africa (WHO, 2011 in Walton and Schbley, 2013; Unicef, 2009). The country is also suffering from a striking shortage of physicians and skilled health attendants. For every 1000 people, there are only 0.5 doctors and 0.2 nurses (Ministry of Health and Family Welfare, 2015). There are approximately 0.58 health worker per 1000 residents against the WHO suggested level 2.28 workers per 1000 persons (The World Health Report, 2006). The distribution of doctors is also geographically uneven and negatively skewed in the rural areas, as doctors have the tendency to live in metropolitan area (WHO, 2011).

Table 1: Trend of mortality and health indicators in Bangladesh from 1990 to 2014

\begin{tabular}{|l|l|l|l|l|}
\hline Indicator & \multicolumn{3}{|c|}{ Year } \\
\cline { 2 - 5 } & $\mathbf{1 9 9 0}$ & $\mathbf{2 0 0 0}$ & $\mathbf{2 0 1 0}$ & $\mathbf{2 0 1 4}$ \\
\hline Life expectancy at birth, total (years) & 59 & 65 & 69 & 70.7 \\
\hline Life expectancy at birth, female (years) & 59 & 65 & 69 & 71.6 \\
\hline Life expectancy at birth, male (years) & 60 & 65 & 68 & 69.1 \\
\hline $\begin{array}{l}\text { Mortality rate among adult female (per 1000 female } \\
\text { adults) }\end{array}$ & & 171 & 137 & - \\
\hline Mortality rate among adult male (per 1000 male adults) & - & 179 & 163 & - \\
\hline Infant mortality rate (per 1000 live births ) & 99.5 & 64.2 & 37.5 & 38 \\
\hline Neonatal mortality rate (per 1000 live births) & 54.1 & 40.7 & 27 & 28 \\
\hline Under 5 mortality rate (per 1000 live births) & 143.6 & 87.7 & 47.2 & 46 \\
\hline Maternal mortality ratio (per 100000 live births) & 551.9 & 375 & 300 & - \\
\hline
\end{tabular}

Source:http://publications.worldbank.org/WDI/indicators and Kassebaum, 2014 in Ahmed et al. (2015); DGHS, 2014

Bangladesh is experiencing a rapid growth in the number of mobile subscribers from its inception in 1993. The country has a comprehensive coverage of mobile network and according to the World Bank collection of development indicators, $540 \%$ population is covered by mobile cellular network (Trading Economics, 2006). The mobile phone is also serving as the major device for internet access. According to BTRC, at the end of year 2015, the total internet connection of the country stood 54.1 million of which 51.5 million were on

mobile phones (Islam, 2016). This wellstructured mobile network and huge number of subscribers eventually put Bangladesh in a favorable position in utilizing mobile based health service. Although Bangladesh is in a favorable position in utilizing mobile based health service, the country still lags far behind in utilizing this potential. In this context, the 
present study was undertaken with the following objectives:

1. To reveal the present situation of Smartphone based e-health service use in the study area.

2. To explore the prospects and challenges in using a Smartphone based e-health service in the study area.

3. To develop a crowdsourcing based health map model to overcome the present constraints and effective prediction of future occurrence of disease outbreak.

\section{Public Health Care Delivery System and Capacity in Bangladesh}

Bangladesh has a relatively widespread public health care delivery system stretched from national to village level. The health service web in the country is composed of hospitals, health centers, community clinics, dispensaries and training centers. Based on the administrative structure of the country, the structure of health service delivery in the country is divided into six hierarchical segments, such as ward in the bottom level followed by the union, upazila (Subdistrict), district, divisional, and national level. A detail of each stratum is present in Table 2.

Table 2: Health care service delivery structure in Bangladesh

\begin{tabular}{|c|c|c|c|}
\hline Level & Service Structure & Important Manpower & Major services \\
\hline Ward & $\begin{array}{l}\text { Community Clinic } \\
\text { Family Welfare Center }\end{array}$ & $\begin{array}{l}\text { Family Welfare Visitor; } \\
\text { Family Welfare Assistants; } \\
\text { Medical Assistant }\end{array}$ & $\begin{array}{l}\text { Referral linkage with higher } \\
\text { facilities; family planning; } \\
\text { immunization programs, } \\
\text { primary health care; } \\
\text { nutrition; sanitation }\end{array}$ \\
\hline Union & $\begin{array}{l}\text { Family Welfare } \\
\text { Center; Community } \\
\text { Clinic; } \\
\text { Union Sub Center; } \\
\text { Rural Dispensary }\end{array}$ & $\begin{array}{l}\text { Doctor; Medical Assistant; } \\
\text { Nurse }\end{array}$ & $\begin{array}{l}\text { Maternal and neonatal } \\
\text { health care; Integrated } \\
\text { Management of Childhood } \\
\text { Illness; Reproductive health } \\
\text { and family planning service; } \\
\text { child delivery; outpatient } \\
\text { service for injuries, wound, } \\
\text { and minor alignment; } \\
\text { treatment of common } \\
\text { disease and first aid }\end{array}$ \\
\hline Upazila & $\begin{array}{l}\text { Upazila Health } \\
\text { Complex; Tuberculosis } \\
\text { Clinic }\end{array}$ & $\begin{array}{l}\text { Upazila Health Family } \\
\text { Planning Officer; } \\
\text { Consultant Doctor, } \\
\text { Residential Medical Officer } \\
\text { (RMO), Medical Officer } \\
\text { (MO); Nurse; Laboratory } \\
\text { Assistant, Pharmacists }\end{array}$ & $\begin{array}{l}\text { Comprehensive emergency } \\
\text { obstetric care, admission } \\
\text { and discharge, normal and } \\
\text { caesarean delivery, maternal } \\
\text { child care; nursing service } \\
\text { and basic laboratory } \\
\text { facilities; immunization; } \\
\text { family planning }\end{array}$ \\
\hline District & $\begin{array}{l}\text { District Hospitals with } \\
\text { Nursing Institute; } \\
\text { General Hospital; } \\
\text { Medical College with } \\
\text { Nursing Institute; } \\
\text { Medical Assistant } \\
\text { Training Institute }\end{array}$ & $\begin{array}{l}\text { Civil Surgeon; Consultant } \\
\text { Doctor; RMOs; MOs; Family } \\
\text { Planning Supervisors and } \\
\text { Officers; Superintendent of } \\
\text { Drugs; Public Health Nurse }\end{array}$ & $\begin{array}{l}\text { All general healthcare; } \\
\text { Operative care; } \\
\text { Rehabilitation; Coordination } \\
\text { with all health care centers; } \\
\text { training, education and } \\
\text { hospital service } \\
\text { management; safe blood } \\
\text { transfusion }\end{array}$ \\
\hline
\end{tabular}

Moinul Islam Sayed, Md. Mamun-ur-Rashid and Rejwana Islam (2019), Journal of e-health Management, DOI: 10.5171/2019.673705 


\begin{tabular}{|l|l|l|l|}
\hline Division & $\begin{array}{l}\text { Medical College and } \\
\text { Hospital with Nursing } \\
\text { Institute; General } \\
\text { Hospital with Nursing } \\
\text { Institute; Institute of } \\
\text { Health Technology }\end{array}$ & $\begin{array}{l}\text { Director General along } \\
\text { with all the important } \\
\text { manpower at district level }\end{array}$ & $\begin{array}{l}\text { Care of all complicated } \\
\text { diseases; rehabilitation care; } \\
\text { training, research and } \\
\text { development; care of } \\
\text { infectious and } \\
\text { communicable disease }\end{array}$ \\
\hline National & $\begin{array}{l}\text { Public Health Institute; } \\
\text { Postgraduate Medical } \\
\text { Institute and Hospital } \\
\text { With Nursing } \\
\text { Institute; Specialized } \\
\text { Health Institute }\end{array}$ & $\begin{array}{l}\text { Director of the Institute; } \\
\text { Principal of Medical } \\
\text { College; Consultant Doctor; } \\
\text { RMOs; MOs }\end{array}$ & $\begin{array}{l}\text { Facilitate higher education; } \\
\text { Provide super specialty care }\end{array}$ \\
\hline
\end{tabular}

Source: Mona (2015)

Despite an extensive infrastructure, the capacity of public health sector in providing quality health service for the citizens is still feeble in Bangladesh (Table 3). Many sick people failed to manage a minimum treatment for their survival. Public health service in Bangladesh is facing a chronic shortage of manpower, resources, and technologies. The government financing in the health sector is still not satisfactory. In terms of health spending as the share of GDP, Bangladesh has remained as one of the lowest countries in WHO South-East Asian region placed above only Myanmar and Indonesia (Ahmed et al., 2015). The number of hospital beds per patient indicates availability of resource of a hospital to serve a patient. In Bangladesh less than one hospital bed is preserved for 1000 population, which is a clear indication of resource constraints in delivering hospital service (WHO, 2012).

Table 3: Public health service capacity in Bangladesh

\begin{tabular}{|c|c|c|c|}
\hline Facility & Indicators & Capacity & Source \\
\hline \multirow{8}{*}{$\begin{array}{l}\text { Health centers, } \\
\text { clinics, and } \\
\text { hospitals }\end{array}$} & Medical University & 1 & \multirow[t]{8}{*}{ MOHFW (2013) } \\
\hline & Upazila Health Complex & 436 & \\
\hline & District Hospitals & 53 & \\
\hline & General Hospitals & 11 & \\
\hline & $\begin{array}{l}\text { Medical/dental /alternative medicine college } \\
\text { hospital }\end{array}$ & 22 & \\
\hline & Infectious Disease Hospitals & 5 & \\
\hline & Chest disease/ TB Hospitals & 13 & \\
\hline & Community Clinics & 12,527 & \\
\hline $\begin{array}{l}\text { Government health } \\
\text { workforce }\end{array}$ & $\begin{array}{l}\text { Physicians } \\
\text { Nurses } \\
\text { Medical technologists } \\
\text { Medical assistants } \\
\text { Domiciliary Staff } \\
\text { Non-medical } \\
\end{array}$ & \begin{tabular}{l|}
11,300 \\
13,483 \\
4658 \\
3694 \\
23,285 \\
218 \\
\end{tabular} & DGHS (2010) \\
\hline \multirow[t]{5}{*}{ Health services } & Persons per hospital bed & 1699 & MOHFW (2013) \\
\hline & No. of doctors per 1,000 population & 0.30 & \multirow[t]{2}{*}{ WHO (2014) } \\
\hline & No. of nurses per 1,000 population & 0.30 & \\
\hline & $\%$ GDP spent on healthcare & $3.5 \%$ & MOHFW (2010) \\
\hline & \% Government budget on health expenditure & 7.4 & DGHS (2010) \\
\hline \multirow[t]{3}{*}{ Health financing } & Out-of-pocket expenditure for health & $64 \%$ & \multirow[t]{3}{*}{ MOHFW (2010) } \\
\hline & Per capita total expenditure on health (U.S.\$) & 26.60 & \\
\hline & $\begin{array}{l}\text { Per cent coming from development } \\
\text { aid/partners }\end{array}$ & 8 & \\
\hline
\end{tabular}

Moinul Islam Sayed, Md. Mamun-ur-Rashid and Rejwana Islam (2019), Journal of e-health Management, DOI: 10.5171/2019.673705 
Massive shortage of skilled human resources in the health sector of Bangladesh is also an acute problem. As identified by WHO, Bangladesh is one of the 57 countries having a critical shortage of health workforce (WHO, 2006). The country is running with an immense shortage of 60,000 doctors and 140,000 nurses (Mahmood, 2012). The ratio of the necessary health workforce for quality service is also stridently unbalanced. For instance, the ration of physician, nurse, and health technician is 1:0.4:0.24, which represents a colossal disparity with FAO suggested ratio 1:3:5 (Ahmed et al., 2015). Not only the number, the distribution of the workforce is also uneven and skewed to urban areas, leaving rural facilities overburdened, understaffed, and insufficiently equipped (Ahmed et al., 2015). According to the World Bank (2012), the public sector health facilities in Bangladesh are poorly equipped with medical devices, instruments and supplies. More than half of the surveyed Maternal and Child Welfare Centers did not have child height measurement scales and 255 surveyed district hospitals lacked minor surgical tools, while about half of the surveyed community clinics didn't have a blood pressure measuring tool or thermometers (World Bank, 2012).

\section{Crowdsourcing in Risk Management: Evidences around the Globe}

With the tremendous concentration of the scholars and recent progress of Web 2.0 technologies, crowdsourcing application has been one of the emerging phenomena in the last decade. The idea of crowdsourcing was first introduced in a Wired Magazine article in June 2006 by Howe (Zhaoand Zhu, 2014; Brabham et al., 2014). Crowdsourcing can be referred to as a distributed problem-solving model where a crowd having no exact size can be involved in finding the solution of a complex problem (Chatzimilioudiset al., 2012). In a typical crowdsourcing process, firstly an organization identifies the tasks to solve a problem, and then the tasks are released to the crowd which is an online community for their contribution. Anyone among the members, who are interested in incentives or facilities given by the organization, can contribute on behalf of the organizations. It is a simple method with powerful impact as it mobilizes expertise and competence. So a vast number of individuals can work individually or in a collaborative manner to accomplish the tasks. After completion, the tasks are submitted to the organization and the organization can further assess the quality of the work done. Wikipedia is an example and a classic form of crowdsourcing process (Zhao and Zhu, 2014; Chatzimilioudis et al., 2012). In Bangladesh, there is no heath map platform for monitoring and reporting public health situations in different regions. For instance, when a massive number of people get affected by a contagious disease, people could hardly know the mode of disease proliferating as there is no designated platform to gather adequate information on contagious disease continuously and disclose it to the public on time. People cannot estimate risk because of scarcity of real-time information about spreading disease. As a result, few people take protection and many others remain indifferent. When a natural disaster or bioterrorism attack happens, the government usually struggles to collect and summarize detail information on a huge number of affected people suddenly. Crowdsourcing in this context can help to overcome the constraints. Crowdsourcing has the potentials in monitoring and reporting physiological, natural, and political emergencies in multiple geographical locations. The United States Department of Defense funded a research project at the University of Virginia to increase community resilience after a crisis (e.g., natural disaster, bioterrorism attack). The premise is that the victims would be better served if it had access to reliable real-time information. They realized the effectiveness of crowdsourcing in this particular event and used crowdsourcing for collecting information (Weaver and Boyle, 2012). 
Ushahidi is a web tool helping people to respond at crises, such as earthquakes and political protests. It develops free and open-source software for data collection, visualization, and interactive mapping as a non-profit software company. The Ushahidi platform was developed in Kenya following the post-election fallout in 2007. It was considered as a way to monitor both violence and peace efforts throughout the country along with catering up-to-date information to the authorities. Ushahidi has since become an important crowdsourcing platform, with applications in India, Mexico, Lebanon, Afghanistan, the Democratic Republic of Congo, Zambia, and the Philippines, ranging from monitoring elections to tracking medicine supplies. The platform can handle reports from diversified data sources, including text messages, email, twitter, and web forms. It has an interactive mapping capability as well as a dynamic timeline tool to track events. Additionally, it can integrate with SwiftRiverfor information processing and analysis and with Frontline SMS for sending alerts to participants (Zook et al., 2010; Weaver and Boyle, 2012).

If the individuals have access to the information about the imminent disaster, he could take necessary initiatives and preparation to minimize the loss during the event. This advance preparation can also safeguard a huge number of lives from looming disaster and make it easier to handle the health crisis with the least efforts. Adequate information can also assist health officials in developing mathematical models to predict the possibilities of the future occurrence of a disaster. For example, prediction can estimate the quantity of the elements, succor, medicine or vaccine that will be required in the near future to handle the crisis. Suppose, the country needs a massive supply of medicine for the imminent crisis, the government could take advance initiatives to dispose the medicine in advance and save precious lives of the citizens.

Proper distribution of aid is another important challenge during the event of an epidemic. If the aid is available, government can estimate the priorities based on diverse Geo-locations. A health map may play a fundamental role showing the location and number of vulnerable people, such as pregnant women, babies and older people. During the crisis, these people should get first priority for receiving succor and medicine. Government can distribute medicine among the hospitals and temporary health camps in an intelligent way, according to the demand in different hospitals and health camps. Government can also monitor the number of different types of patients in different hospitals and determine the most suitable locations to establish temporary health camps during a crisis. The Haiti earthquake in 2010 has become a turning point in disaster response because of the support provided by collaborative communities such as OpenStreetMap, Ushahidi, CrisisMappers, Google MapMaker and others(Van de Walle andTuroff,2008; Weaver and Boyle,2012).The Sahana; a free and open source disaster management system is an emergency management and a disaster preparedness software developed by the Sahana Software Foundation. Sahana software was originally developed by members of the Sri Lankan IT community who wanted to find a way to apply their talents towards helping their country to recover from the immediate aftermath of the 2004 Indian Ocean earthquake and tsunami.

During a health crisis, time should be utilized in an effective and intelligent way as delivering medicine or succor at the right time can save many lives. As health map shows real time public health status in different areas and can also visualize the prediction, it will have a great impact on the timely realization about the severity of situations. Nonetheless, if the public has reporting opportunities and government has direct access to these reports, government can also determine their efficiency and lacks in crisis management. So, authority may bring necessary changes in the approaches to crisis management in time. The widespread use of Smartphone allows people to post geo-location specific reports and pictures with ease. Disaster

Moinul Islam Sayed, Md. Mamun-ur-Rashid and Rejwana Islam (2019), Journal of e-health

Management, DOI: 10.5171/2019.673705 
management teams would be more benefited from the reports of more observers.

Crows was developed by the Pittsburgh Independent Media Center for coverage of the G20 summit and subsequent protests in Pittsburgh in September 2009. Crows has not become popular as a crowdsourcing platform, may be because of its limited functionality. By using crows, one can submit reports and view them on Google map. It also includes widgets for Twitter, Flickr, YouTube, and Podcast integration as well as a Smartphone compatible mobile version of the website. Ushahidi and Sahana systems were too large to manage limited resources, but crows, has made smaller size management more feasible. The lack of certain features made it easy to customize the platform as our own needs(Weaver and Boyle, 2012).

The International Network of Crisis Mappers (Crisis Mappers Net) is the largest and most active international community of experts, practitioners, policymakers, technologists, researchers, journalists, scholars, hackers and skilled volunteers engaged at the intersection of humanitarian crises, new technology, crowd-sourcing, and crisis mapping. The Crisis Mappers Network was launched at the first International Conference on Crisis Mapping (ICCM) in 2009. Crisis Mappers leverage mobile \& web-based applications, participatory maps \&crowdsourced event data, aerial \& satellite imagery, geo-spatial platforms, advanced visualization, live simulation, and computational \& statistical models to power effective early warning for rapid response to complex humanitarian emergencies (Chan, Colombo, and Musani, 2012).

In the event of a contagious disease outbreak or natural disaster, the government in many developing countries, including Bangladesh is not sufficiently prepared or equipped to gather and disseminate information to the public quickly at the right moment. Experiences around the globe confirmed the fact that developing a health map platform using an effective e-health system as a source of information would be a decidedly valuable real-time tool for managing and understanding situations rather than relying heavily on retrospective analysis.

\section{Methodology}

This study was conducted in selected villages and district headquarters of Barisal and Jhalokathi in Bangladesh. To achieve the objectives, this research adopted mixed method approaches, i.e. blended both quantitative and qualitative methods for better understanding of the phenomenon under study. The population considered in this study encompasses general people, patients, and physicians. Using purposive sampling method, a total of 200 questionnaires were supplied to the respondents of which 108 gave the complete feedback. Among the total questionnaires, 20 questionnaires were filled-up by the physicians serving in the Sher-E-Bangla Medical College Hospital, Barisal. The structured questionnaire sought information on general characteristics of the respondents, health related information seeking behavior, sources used for receiving health related information, awareness, use and interest in e-health service. The questionnaire was developed based on brain storming and expert opinion. This research also conducted 10 in-depth interviews with the physicians, 10 informal interviews and 2 case studies with the patients, 4 focus group discussions (FGD) one each with doctors, patients, intern doctors, and medical students. The questionnaire was distributed directly among the people, but in some cases, where the patient was unable to fill-up questionnaire, it was filled-up by interviewer according to the answer given by the patients. For analyzing data, this study used descriptive statistics such as mean, median, mode, frequency, observed ratio, etc. and adopted SPSS 16.0 software.

\section{Result and Discussion}

\section{General characteristics of the respondents}

According to the general information displayed in Table 4, the mean age of the 
respondents were 31.3 years along with the standard deviation 8.46. A little less than two third $(72 \%)$ of the respondents were male, while the rest $28 \%$ were female. A slightly more than three quarters (76\%) of the respondents didn't use Smartphone, while the rest $24 \%$ used Smartphone

Table 4: General characteristics of the respondents

\begin{tabular}{|l|l|l|l|l|l|l|}
\hline Variable name & Scale & Mean & Sd & Median & Mode & OR* \\
\hline Age & $\begin{array}{l}\text { A score of 1 for each } \\
\text { completed year }\end{array}$ & 31.13 & 8.46 & 30 & 25 & $17-60$ \\
\hline Gender & Male =72 (78\%); Female =28(28\%) & & & \\
\hline Smartphone use & Yes = 24 (24\%); No =76(76\%) & & & \\
\hline
\end{tabular}

Note: $O R={ }^{*}$ Observed range

\section{Health Related Information Seeking Behavior}

Data allied to health related information seeking behavior in Table 2 illustrates that apart from a small proportion (11\%), the lion's share of the respondents didn't go to the doctor in minor health related problems. The reason for not visiting a physician encompasses the over crowdedness of the hospital, high visiting charge of a physician, high distance of the hospital from the patient's residence, and overindulgence of the patients with daily chores. In an in depth interview, an individual called Mohammad Sorwar from Barisal city said-

'People living in the adjacent areas of Shere-Bangla Medical College Hospital, Barisal usually don't prefer to go to the hospital for the treatment, rather they frequently take treatment from drug dispensaries. The reasons for not going to hospital embrace huge patient rush to the hospital and less inclination of the physicians in providing quality treatment.'
Table 5 mirrors that the respondents used television as the major source of receiving health related information followed by cell phone based sources and the internet. A conspicuous section of the respondents (29\%) also obtained health related information from newspapers. The telecommunication technology in Bangladesh is proliferating rapidly and eventually mobile phone is gaining vast popularity as a communication medium. The government of Bangladesh also recognized mobile phone as a very important medium in disseminating crucial information. For instance, at present, the government sends SMS to the mobile subscribers to inform about any imminent crisis. The mobile phone also acts as an important device for access to the internet throughout the country. So, with the boom in the number of mobile phone subscribers, the internet users are also elevating simultaneously. Social media like Facebook, Twitter, etc., nowadays, evolved as a high-flying source of information. However, as these social media are internet 
based, this research counted on all of them

in general as the internet.

Table 5: Health related information seeking behavior of the respondents $(n=100)$

\begin{tabular}{|c|c|c|}
\hline Items & $\begin{array}{c}\text { Yes } \\
\text { Frequency (\%) }\end{array}$ & $\begin{array}{c}\text { No } \\
\text { Frequency (\%) }\end{array}$ \\
\hline Go to physicians for minor health related problems & $11(11 \%)$ & $89(89 \%)$ \\
\hline \multicolumn{3}{|l|}{ Causes of not going to doctor } \\
\hline Visiting doctor is expensive & $67(67 \%)$ & $33(33 \%)$ \\
\hline The hospital is far away from home & $49(49 \%)$ & $51(51 \%)$ \\
\hline The hospital is very crowded & $79(79 \%)$ & $21(21 \%)$ \\
\hline Busy with other affairs & $51(51 \%)$ & $49(49 \%)$ \\
\hline Others & $6(6 \%)$ & $94(94 \%)$ \\
\hline \multicolumn{3}{|l|}{ Sources used for receiving information } \\
\hline Television & $72(72 \%)$ & $28(28 \%)$ \\
\hline Radio & $12(12 \%)$ & $88(88 \%)$ \\
\hline News paper & $29(29 \%)$ & $71(71 \%)$ \\
\hline Cell-phone & $51(51 \%)$ & $49(49 \%)$ \\
\hline Internet & $42(42 \%)$ & $58(58 \%)$ \\
\hline Local government advertisement & $13(13 \%)$ & $87(87 \%)$ \\
\hline g) Others & $6(6 \%)$ & $94(94 \%)$ \\
\hline
\end{tabular}

\section{Awareness, Use, and Interest in e-health Service}

Data arranged in Table 6 shows that more than half $(54 \%)$ of the respondents were aware about e-health services, while only a small proportion (22\%) of them ever used e-health services. Interestingly, more than three quarters $(76 \%)$ of the respondents had an interest in e-health service. Not only were the patients, but the physicians were also in common consensus regarding the widespread benefits of e-health services. In an FGD in Sher-e-Bangla Medical College
Hospital, Barisal, the physicians of the Department of Surgery and Obstetrics opined that-

'e-Health has the capacity of mobilizing quality health service to the doorstep of people residing in remote areas. It can save valuable life of critical patients and pregnant women by providing right medicine at the right time. For instance, a heart patient can survive for a few hours if the right medicine is used immediately after the heart attack'. 
Table 6: Respondent's awareness, use, and interest in e-health service $(n=100)$

\begin{tabular}{|l|c|c|}
\hline \multicolumn{1}{|c|}{ Dimensions of e-health service } & Yes & No \\
& Frequency (\%) & Frequency (\%) \\
\hline Awareness about e-health services & $54(54 \%)$ & $46(46 \%)$ \\
\hline Ever used e-health service & $22(22 \%)$ & $78(78 \%)$ \\
\hline Interest in e-health service & $76(76 \%)$ & $24(24 \%)$ \\
\hline
\end{tabular}

At present, in Bangladesh, there is no system in place to detect, monitor or predict contagious diseases. So, if a sudden health crisis occurred, it is not possible to assess the situation immediately. This time lag has a profound negative effect on the management and organization of the activities for successful management of the crisis. Figure 1 shows that $76 \%$ people surveyed in this study did not receive any information in advance about contagious diseases in the study area, whereas almost all the respondents posited that timely and sufficient information regarding contagious disease outbreak can be very useful for public health management in Bangladesh. Available information will assist the citizens to estimate the degree of risk of a particular disease in advance, hence helps to take necessary precaution before the disease outbreak. In advance information can also assist the government in effective distribution of medicine and efficient management of the workforce.

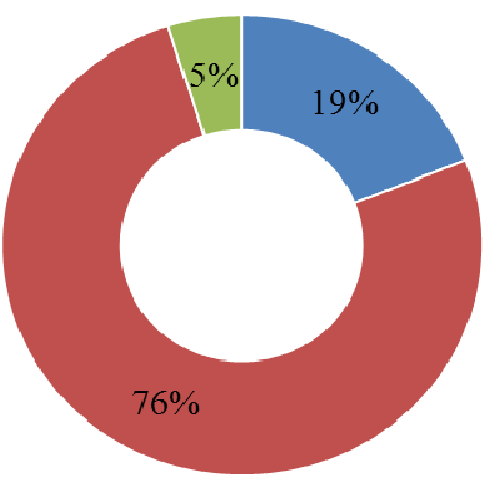

- No comment

- No Information

Little Information

Fig. 1: Access to information about contagious disease outbreak

Health map is a dynamic system that visualizes the public health situation, contagious disease outbreak and proliferation, and other crucial real time health information on a map. Deplorably, at
Present, there is no health map platform in Bangladesh. However, the respondents consulted in this study were very enthusiastic about health map. About 91.49\% respondents reside in cities 
thought that health map can be very useful for them, while $62.26 \%$ rural residents had similar opinions. Three quarters $(75 \%)$ of the physician respondents were in agreement that health map is necessary for public health management. Respondents feel that communicable diseases like tuberculosis, viral fever, etc. should be visualized on map for better control and management. If people can estimate the risk of imminent diseases, they will be able to take early precaution, which in turn can contribute to the effective control and management of the diseases.

Table 7: Perceived necessity of health map in Bangladesh by different categories of the respondents $(n=100)$

\begin{tabular}{|l|c|c|c|}
\hline \multicolumn{1}{|c|}{ Respondent } & \multicolumn{3}{|c|}{ Percentage } \\
\hline & No need & May be & Necessary \\
\hline Respondents from city & 2.13 & 6.38 & 91.49 \\
\hline Respondents from village & 5.66 & 32.07 & 62.26 \\
\hline Doctors & 0 & 25 & 75 \\
\hline
\end{tabular}

\section{Challenges of existing e-health services}

Along with numerous convincing benefits, e-health services also have a number of challenges. For example, internet based ehealth service needs a Smartphone for enjoying service. Regrettably, only $24 \%$ of the respondents (Table 4) possessed Smartphone. In Bangladesh, the major section of population evolved from lower middle class to low income strata, so Smartphone based e-health service may not be accessible to a large section of the population. The high cost of internet service is also an obstacle which limits the use of e-health service. Due to high call toll, the respondents also considered Cell phone call based e-health services expensive. In an in-depth interview, a shop keeper named Khairul Hassan from Barisal city said-

'I have received quality treatment via mobile phone health line for treating my eye problem. However, the cost of the call seems expensive, as I had to talk with the doctor for several minutes.'
A minimum level of literacy is mandatory for receiving health advice via internet or cell phone. Many medical terms don't have any Bengali name and the names of the drugs are also in English. So, it is difficult to consume the health related information if the service receiver is illiterate. The ehealth service is only suitable for the treatment of minor diseases and can provide support at the primary stage of critical diseases. This service is not suitable for critically ill patients needing intensive care for a long period of time under the supervision of physicians.

\section{Present Status of e-health Services in Bangladesh}

Despite a huge potential of IT deployment in healthcare sector in the country, the use of IT systems for healthcare has not been developed so far. The existence of the use of IT system in healthcare is limited to only e-prescribing services executed by the mobile phone operators. Among these services, Grameenphone's doctor helpline has been the most popular service. Through this service, patients can talk with doctors via a mobile phone call and explain

Moinul Islam Sayed, Md. Mamun-ur-Rashid and Rejwana Islam (2019), Journal of e-health

Management, DOI: 10.5171/2019.673705 
their health related problems and subsequently the doctor give them instructions. The existing mobile based ehealth services have several bottlenecks. Mobile based services allow only voice transmission, so the patients cannot use images or videos for better explanation of the disease, such as skin diseases. On many occasions, the healthcare services needs to be continuous, i.e. a patient need to be under supervision of the same doctor for a longer period of time but the existing ehealth systems failed to ensure this opportunity. Whenever a patient calls a doctor, he/she has to face a new doctor with every new call. Procedure of finding an appropriate physician is also very complex. The patients have to follow a complicated multistage calling system to reach a doctor. Providing appropriate medical support needs an array of information from the part of the patient, such as body temperature, heartbeat, blood sugar level, body weight, etc. Lamentably, most of the patient can't provide all these information correctly when requested. As a result, the physicians can't provide appropriate suggestion except some minor diseases such as fever, vomiting, headache, etc. Another major problem limiting ehealth service in Bangladesh is the absence of e-health policy. In the current e-health system, patients are at risk because the doctors don't have any liabilities for the flawed instruction.

Despite several problems, this service is experiencing an upward trend of popularity for some reasons. In general, when a patient meets a doctor face to face, the majority of the doctors showed disinclination to the patients. On the contrary, when a patient contacts a doctor via phone calls, the doctor seems more attentive than usual. Phone callbased health service can also save money and valuable time of the patients. However, among the respondents using e-health service, a major section (62\%) had complains about the existing mobile based e-health service, while the rest $38 \%$ were satisfied.

\section{$A$ Proposed Crowdsourcing based $E$ - health Service Model}

Considering the existing bottlenecks of ehealth services and health related information dissemination process as well as the opinion of the patients and physicians, this research proposed a model for crowdsourcing based health map in Bangladesh. In the beginning, a Smartphone application is used for collecting and reporting health data from the mobile subscribers and these data will be processed in a web based system. When any user feels a health problem, he will report this via Smartphone application filling a report form (see Figure 2 for a sample form) with necessary images or videos if needed. This report will proceed to the doctor assigned for giving medical advice in this area, where the users reside. When a doctor gets a report from any patient, all previous health records as well as present health status about that patient will appear in the Web app. After analyzing the pool of data, the doctor will provide suggestions or prescribe necessary medicine. If the doctor needs supplementary information to identify the health problem correctly, the doctor can directly make a phone call to the patient or send a query message to the patient. 


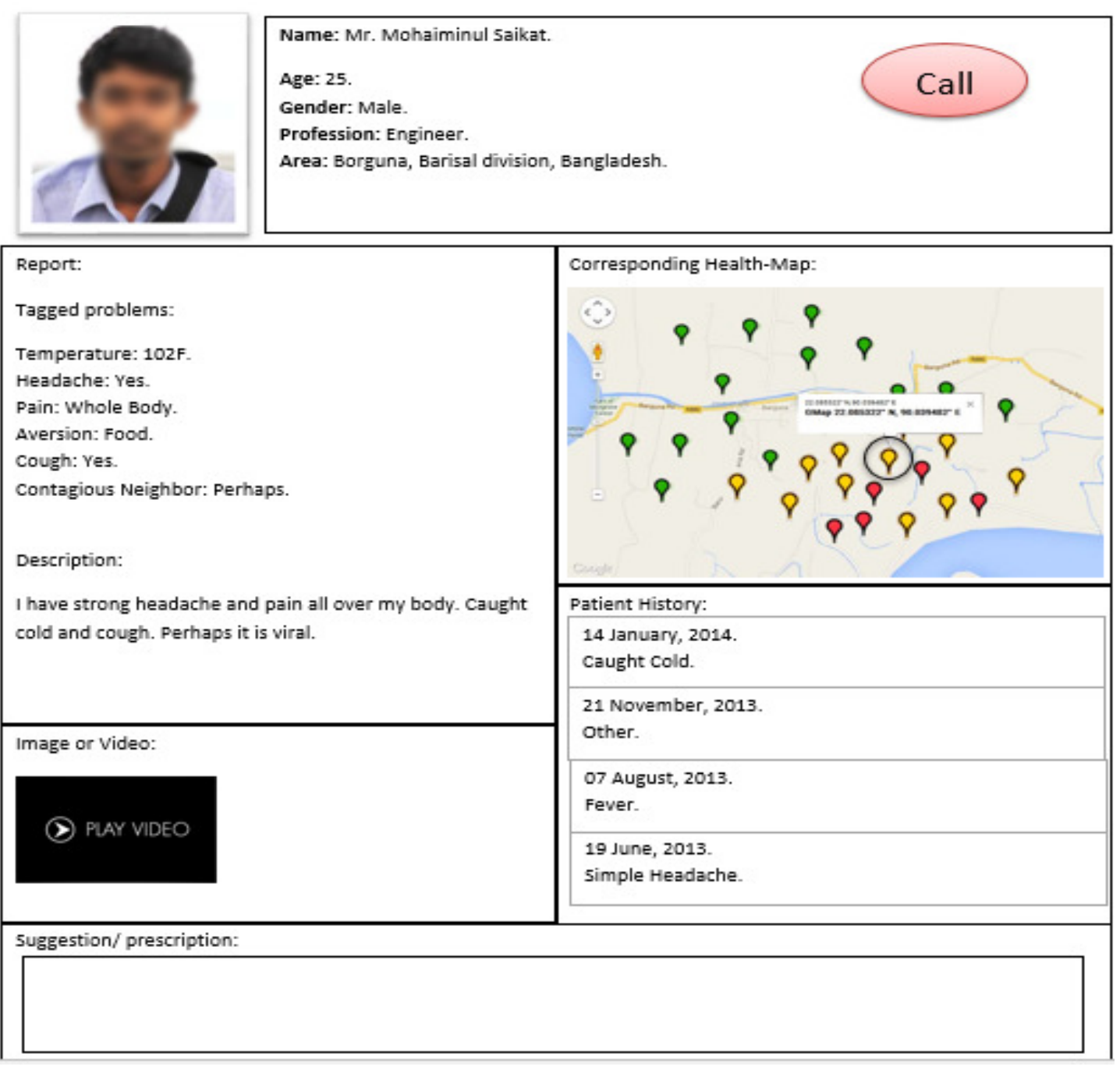

Fig. 2: A snapshot of web based health form for the patients

Moinul Islam Sayed, Md. Mamun-ur-Rashid and Rejwana Islam (2019), Journal of e-health Management, DOI: 10.5171/2019.673705 


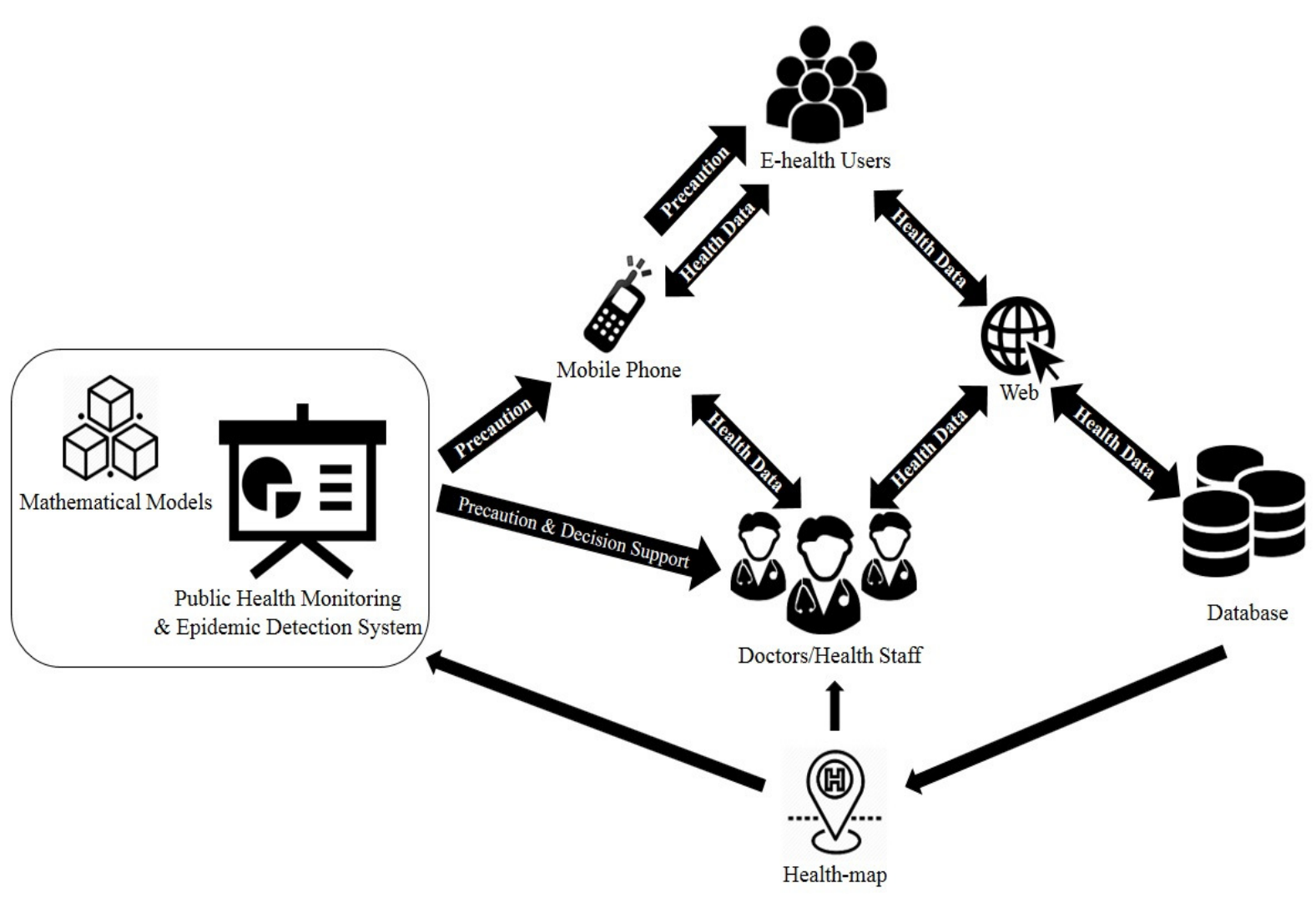

Fig. 3: A proposed model of crowdsourcing based health map

A central database will store all of the patient's record. This big data will help the concerned entities to analyze health and disease status in different geo-locations. If the same infectious disease status reported frequently from numerous users in a particular time period in a specific location, then with the help of proper mathematical models, the system will be able to identify the possibility of any contagious disease outbreak. Analyzing the trend of spreading cause, rate, and the direction, the system will be able to predict possible future outbreak. The Health Map will show every progress and downfall of public health status in the affected area in a continuous basis. The government as well as other humanitarian health organizations will be incorporated into the system for spatial and temporal monitoring of the health situation to take timely steps in building awareness, medicine and other resource supply, and better management of human resources.

\section{Conclusion}

This research implies that crowdsourcing based e-health map can improve efficiency in the public health crisis management and Bangladesh due to its widespread cell phone network coverage and its conducive position in using a crowdsouring based health map to monitor and manage public health crisis. Despite having a promising future, at present, the e-health service in Bangladesh is feeble and need extensive improvement. This research suggested a web based system and Smartphone based mobile application which will assist in accumulating and analyzing health data. The analysis of the data will help to predict geographical location specific future occurrence of health crisis, hence assist both the patients and concerned health organization in building awareness and timely efficient handling of the crisis situation to save precious lives and valuable resources. The model suggested in 
this study might be helpful to reduce the gap of quality of health service based on geographical locations, such as rural and urban areas and help to utilize limited resources effectively in managing health crisis in Bangladesh. However, to find out a more parsimonious crowdsourcing based e-health model, this study suggests further research as the geographical coverage, diversity of respondents, and dimensions considered were limited in this study.

\section{References}

1. Ahmed, S. M., Alam, B. B., Anwar, I., Begum, T., Haque, R., Khan, J. A. M., Osman, F. A. (2015).Bangladesh Health System Review.Health System in Transition, 5(3). Retrieved June 30, 2018 from http://apps.searo.who.int/PDS DOCS/B54 09.pdf

2. Brabham, D.C., Ribisl, K.M., Kirchner, T. R. and Bernhardt, J. M. (2014),'Crowdsourcing applications for public health',American Journal of Preventive Medicine, 46(2), 179-87.

3. Chan, J. L., Colombo, R. and Musani, A. (2012), 'Mapping libyan health facilities-A collaboration between crisis mappers and the world health organization', 9th International Conference on Information Systems for Crisis Response and Management, April 2012, Vancouver: Simon Fraser University, 28

4. Chatzimilioudis, G., Konstantinidis, A., Laoudias, C. and Zeinalipour-Yazti, D. (2012),'Crowdsourcing with smartphones',IEEE Internet Computing, 16(5), 36-44.

5. DGHS.(2010). Secondary and Tertiary Health Care Facilities in Bangladesh. Dhaka: DGHS.

6. DGHS. (2014). Bangladesh Demographic and Health Survey, 2014 .National Institute of Population Research and Training Ministry of Health and Family Welfare Dhaka, Bangladesh

7. Islam, M. Z. (2016), 'Mobile users rise $11 \mathrm{pc}$ in 2015', [Retrieved April 10,
2017],Available:http://www.thedailystar.n et/business/telecom/mobile-users-rise$\underline{11 p c-2015-203869}$

8. Mahmood, S. A. I. (2012). Health systems in Bangladesh.Health Systems and Policy Research, 1(1), 1-4. doi: 10.3823/1100

9. Mona, M. (2015).Health care delivery system in Bangladesh. Retrieved on 25 July 2018

from http://nursingexercise.com/health-caredelivery-system-bangladesh/

10.MOHFW (2010). Health Population \& Nutrition Sector Strategic Plan (HPNSSP) 2011-2016. Planning Wing.Dhaka.

11.MOHFW (2013).Health Bulletin. Management Information System, DGHS. Dhaka.

12.The World Health Report. (2006), 'Working together for health', Geneva: World Health Organization, [Retrieved March 17, 2018], http://www.who.int/whr/2006/en/

13.Trading Economics (2006), 'Bangladesh - population covered by mobile cellular network', [Retrieved June 17, 2018],Available:https://tradingeconomics. com/bangladesh/population-covered-bymobile-cellular-network-percent-wbdata.html

14.UNICEF. (2009), 'Maternal and neonatal health in Bangladesh', [Retrieved April 20, 2018], Available: https://www.unicef.org/bangladesh/Mate rnal_and_Neonatal_Health.pdf

15.Van de Walle, B. and Turoff, M. (2008), 'Decision support for emergency situations', Information Systems and EBusiness Management, 6(3), 295-316.

16.Walton, L. M. and Schbley, B. (2013), 'Cultural barriers to maternal health care in rural Bangladesh', Online Journal of Health Ethics, 9(1),[Online], [Retrieved May 16, 2017], Available: http://dx.doi.org/10.18785/ojhe.0901.03 
17.Weaver, A. C. and Boyle, J. P. (2012), 'Using Crowdsourcing to Enhance Crisis Management', Proceedings of the International Conference on Frontiers in Education: Computer Science and Computer Engineering (FECS), vol.2, Las Vegas Nevada:CSREA Press, 551-555.

18.WHO (2006). World health report 2006: working together for health.

19.WHO (2014). Bangladesh. Retrieved 28 July, 2018, from http://www.who.int/workforcealliance/co untries/bgd/en/

20.WHO.(2012). 'Joint review of the National Malaria control programme, Bangladesh'. India

21.World Bank Report (2010), 'Poverty assessment for Bangladesh: creating opportunities and bridging the East-West Divide', Bangladesh Development Series No. 26
22.World Bank (2012).Bangladesh Health Facility Survey 2011.Dhaka.

23.World Health Organization \& Bangladesh.Ministry of Health and Family Welfare. ((2015 rof srotcaf sseccuS ‘ , ,Bangladesh' :women's and children's health Retrieved April ] .World Health Organization :Available , , 17 http://www.who.int/iris/handle/10665/1 $\underline{78623}$

24.World Health Organization.(2011), 'ATLAS eHealth country profiles', Global Observatory for eHealth series - Volume 1.

25.Zhao, Y. and Zhu, Q. (2014), 'Evaluation on crowdsourcing research: Current status and future direction', Information Systems Frontiers, 16(3), 417-434.

26.Zook, M., Graham, M., Shelton, T. and Gorman, S. (2010).'Volunteered geographic information and crowdsourcing disaster relief: a case study of the Haitian earthquake',World Medical \& Health Policy, 2(2), 7-33. 